\title{
Post exposition to etoricoxib in patients with negative oral drug provocation tests
}

\author{
Thais Sterza ${ }^{1 *}$, Pedro HR Fernandes ${ }^{2}$, Cristiane Momoi ${ }^{2}$, Luis Felipe Ensina ${ }^{2}$, Inês Cristina Camelo Nunes ${ }^{2}$, \\ Dirceu Solé ${ }^{2}$
}

From 3rd WAO International Scientific Conference (WISC) 2014

Rio de Janeiro, Brazil. 6-9 December 2014

\section{Background}

The etoricoxib can be used as a therapeutical alternative to patients with hypersensitivity to non-steroidal antiinflammatory drugs (NSAIDs). The aim of this study was to evaluate the use of etoricoxib in daily life of patients with negative oral drug provocation tests (DPT).

\section{Methods}

Patients with hypersensitivity to NSAIDs that performed a DPT with etoricoxibe between january/2013 and june/ 2014 were contacted by phone and asked about posterior etoricoxib drug usage and the occurrence of reactions. Those who had not used again were asked the reasons for not using.

\section{Results}

Forty-one patients were tested, all with negative results. Thirty seven of them (90\%) were contacted and $28(76 \%)$ remembered the tested drug's name. Twelve of them (32\%) had used the drug again without any reaction. Twenty five patients were not re-exposed: 18 did not need, 4 were afraid of a new reaction and 3 used another alternative. Of the 4 patients who were afraid to use the drug again, 3 of them had presented anaphylaxis symptoms with other NSAIDs.

\section{Conclusions}

Most of the patients exposed to etoricoxib DPT haven't been exposed again to the drug. Of those who were afraid to use the drug again, most had a severe reaction history to NSAIDs.
Authors' details

${ }^{1}$ Emescam College of Health Sciences, Brazil. ${ }^{2}$ Federal University of São Paulo, Brazil.

Published: 8 April 2015

doi:10.1186/1939-4551-8-S1-A186

Cite this article as: Sterza et al:: Post exposition to etoricoxib in patients with negative oral drug provocation tests. World Allergy Organization Journal 2015 8(Suppl 1):A186.

${ }^{1}$ Emescam College of Health Sciences, Brazil

Full list of author information is available at the end of the article

Submit your next manuscript to BioMed Central and take full advantage of:

- Convenient online submission

- Thorough peer review

- No space constraints or color figure charges

- Immediate publication on acceptance

- Inclusion in PubMed, CAS, Scopus and Google Scholar

- Research which is freely available for redistribution
C Bïomed Central 